\title{
The Global Crisis Brought about by SARS-CoV-2 and Its Impacts on Education: An Overview of the Portuguese Panorama
}

\author{
Maria José Sá, ${ }^{1}$ Sandro Serpa ${ }^{2}$
}

1. CIPES-Centre for Research in Higher Education Policies, Portugal

2. University of The Azores, CICS.UAc/CICS.NOVA.UAc \& NICAUAc, Portugal

\begin{abstract}
The emergence of COVID-19 caused by the SARS-CoV-2 virus at the end of 2019 changed the face of the world. Deep consequences are being felt across the whole world at all levels. This opinion piece aims to provide a picture of the Portuguese educational scenario, specifically the impact of COVID-19 in education and government measures to mitigate it, the hindrances and the challenges ahead.
\end{abstract}

Sci Insigt Edu Front 2020; 5(2):525-530.

Doi: 10.15354/sief.20.ar039

Keywords: COVID 19; Epidemic; School Suspension; Online Education

About the Author: Maria José Sá, CIPES - Centre for Research in Higher Education Policies, Portugal.Email: maria.sampaio.sa@gmail.com.

Correspondence to: Sandro Serpa, Assistant Professor, Department of Sociology, Faculty of Social and Human Sciences, University of The Azores; Interdisciplinary Centre of Social Sciences-CICS.UAc/CICS.NOVA.UAc; Interdisciplinary Centre for Childhood and Adolescence - NICA - UAc, Portugal. Email: sandro.nf.serpa@uac.pt.

Conflict of Interests: None. 


\section{Introduction}

$\mathrm{W}$

HEN the novel coronavirus (Severe Acute Respiratory Syndrome Coronavirus 2, SARS-CoV-2) first emerged in December 2019, the world was not prepared for what came right after. The virus quickly spread to Europe and, in a few weeks, strayed into a planetary scale. The world realized that this deadly virus was unlike others of the kind, which only attacked distant and underdeveloped countries with a poor health system. Now the whole world was facing an enemy that hit almost all countries worldwide, with different degrees of intensity, showing no country was safe, regardless the strength of their economy or the development of their healthcare system. Governments quickly put in place measures that sought to prevent COVID-19 from spreading, but in a few weeks, the number of infected citizens and the death toll was daunting.

Thus, the world had to quickly adapt to this reality, as this scenario is expected to remain dynamic (Abajo, 2020). Supra-national entities such as the World Health Organization (WHO) - that declared a state of pandemic (Teles, 2020), the United Nations (UN) and, at the European level, the European Union, as well as national governments, swiftly took severe measures that aimed to contain the spread of the virus. Yet, the face of the planet changed almost overnight, as - borrowing a phrase from a popular band it was the end of the world as we knew it. While the changes traverse the whole spectrum of society, in the economic, societal, environmental and other spheres, the focus of this opinion piece is the educational arena in Portugal, notably the changes that took and are taking place; the strategies put in place the hindrances and the opportunities that are emerging with this shift in the educational paradigm.

\section{Methods}

The methodology used in this opinion piece consisted of a collection and analysis of publications and other documents that directly focus on this topic. Furthermore, the authors consulted Portuguese By-Laws and other legal documents, as well as informative websites on this very current problem.

\section{COVID-19: Some Notes}

The last global pandemic that the world has witnessed was the Spanish flu, caused by the influenza virus H1N1 from January 1918 to December 1920. This pandemic infected around 500 million people and claimed the lives of between 50 and 100 million people across the planet, which made it one of the deadliest pandemics in human history. After this pandemic, others broke out, such as H5N1, H1N1, Ebola, MERS-CoV and, more recently, the Zika virus, but with far fewer casualties than the Spanish flu.

Currently, the planet is experiencing a similar pandemic, caused by the SARSCoV-2 virus. Since its first emergence, it rapidly spread to Europe, with Italy being the first severely hit country (where the death toll is already higher than in China), followed by Spain, the UK, France, Germany and a bit all European countries. Countries in the 
North and South American continent have also been hit by the virus. As of 11 March 2020, the date when WHO's Director-General declared COVID-19 a global pandemic, almost 120,000 cases of COVID-19 were reported worldwide by more than 100 countries. As of 25 March 2020, ECDC (2020a, online) reported 416,916 cases of COVID19 , including 18,565 deaths. This is indicative that this virus is highly contagious, spreading rapidly through contaminated objects (e.g., elevator buttons or restroom taps) or virus aerosolization in a confined public space (e.g., restrooms or elevators). Furthermore, although a vaccine is being developed in several countries, there is a significant time frame between its creation, development, testing and mass production, and its use by the population at the global scale. For the time being, neither vaccine nor strong evidence on the effectiveness of potential therapeutic agents is available (ECDC, 2020b, online). Thus, other measures have been put in place by many countries to mitigate the impact of the epidemic: social distancing measures (notably, the immediate isolation of symptomatic persons, the suspension of mass gatherings, social distancing measures at workplaces and measures in and closure of schools); ensuring the public is aware of the seriousness of COVID-19; prevention and control of COVID-19 in hospitals and longterm care facilities; the training for all staff of healthcare facilities; rational approaches to limited resources; and surveillance systems for detecting cases and assessing community transmission (ECDC, 2020b, online).

\section{The Portuguese Reality}

\section{Current Situation}

As of March 26, 2020, Portugal recorded 3,544 citizens infected, 22,257 under assessment and 60 deaths. The North of the country (with 1,858 positive cases and 28 casualties) and the region of the capital, Lisbon (1,082 positive cases and 18 casualties), were the most affected by the disease (DGS, 2020a, online). The Portuguese government swiftly put in place measures and a national plan to prepare for the epidemic and respond to it as effectively as possible (DGS, 2020b, online). This pandemic will certainly (and, in some cases, already is) have a profound impact in all contexts, namely the societal, economic and environmental ones. However, the focus of this work is the educational arena and the changes underway in Portugal. This is addressed next.

\section{The Impact of COVID 19 in Education and Government Measures to Mitigate It}

Portugal learnt from the unfortunate experience of other European countries, especially Italy, and shut down all educational institutions, from pre-school to higher education, on March 13, 2020. Before that, several higher education institutions (HEIs) had closed their campuses due to the emergence of coronavirus, which infected members of the academic community. Classroom classes were suspended, as well as live student tutorial support. These activities started being developed via the Internet, and HEIs used their specific internet platforms (e.g., Moodle) or other online tools, such as Zoom, for ex- 
ample, and e-learning became the only possible formal learning overnight. At the remaining educational levels, the government created a website where several online tools are provided to teachers (e.g. Simple Scripts, Colrd, Inkscape and Sketchpad, just to name a few (Portuguese Republic, 2020a, online). Furthermore, teachers also use the email to send students exercises, which they complete and return also by e-mail. In many schools, students carry out online tests and livestream the presentations of the exercises they prepare at home. With these measures put in place, the Portuguese Ministry of Education seeks to ensure that the regular school year and student learning are not jeopardized or, at least, the negative consequences of schools' shutdown are mitigated (Portuguese Republic, 2020, online).

\section{The Hindrances}

Portugal has been preparing its population to the technologic advancements. The government's major strategy encompasses the Portugal EnCoDe.2030 programme, whose main goal (and, simultaneously, challenge) is to train and qualify the Portuguese population in digital competences (Portuguese Republic, 2020b, online). Yet, this project is rather recent and much has still to be done in technologic and digital terms. Only $71.5 \%$ of Portuguese households have a computer with Internet and broadband Internet connection, that is, one in four Portuguese citizens does not have a computer at home (PORDATA, 2020, online). With the government and schools assuming that all students (and teachers, for that matter) have access to a computer with an Internet connection, this may be a serious hurdle, even more so because the country is on complete lockdown as of March 18, 2020 (Decree no. 2-A/2020) and students/teachers cannot leave their homes to go to a library, for instance.

The reality of the conditions, both in terms of lack of training and competences and technical equipment on the part of teachers - which, ultimately, entails that they have to buy the necessary equipment with their money - and also the lack of a technical structure at the national level that allows such a large number of people in simultaneous online connection, seems not to be the most conducive to successful distance learning. The same applies to students, given that, in general, the most disadvantaged are those who need more monitoring. An example taken from a March 26, 2020 news story is illustrative of this reality:

"Teachers are getting exhausted, after more than a week of distance classes due to Covid-19. They had to adapt ways of teaching and even buy equipment and licenses to use online tools [...] Teachers had to reinvent ways of teaching and, for many, digital platforms were unknown ground. At least, until last week." (SIC News, 2020, online).

\section{Final Remarks}

The portrait of Portugal and the status of education offered shows that the government worked hard and quickly to seek to overcome the potential negative effects of the SARS-CoV-2 pandemic in education at all levels. There are difficulties to face, mostly 
because digital competences, computers and access to the Internet are not widespread through the Portuguese population. Some questions need to be put, and the answers to them will dictate the success or failure of this novel educational system: is the country prepared for a hypothetical shutdown of all schools extended in time? Do all students in compulsory education have access to a computer with access to the internet? Are parents prepared to support their children, encouraging them to study and monitoring their learning? Has the necessary investment been made to provide schools with adequate and safe e-learning platforms and tools? Has there been a correct teacher training plan in recent years that enables these professionals to teach in the e-learning modality, not only in terms of technological competences but also in teaching-learning strategies? Can parents stay at home to support and help their children without being having cut on their payrolls or even put their jobs at risk? These are issues that need to be carefully thought about.

However, the reality the country is experiencing brought about by the coronavirus should not be viewed as a set of hurdles, but rather as a challenge and an opportunity to change and to innovate in the educational and pedagogical field. Whether Portugal is ready to fully embrace this challenge remains to be seen.

\section{References}

Abajo, F.J.G. (2020). Simple mathematics on Covid-19 expansion. Preprint. https://doi.org/10.1101/2020.03.17.20037 663.

CIDRAP (2020, online). Study: COVID-19 may spread in several different ways. Available at http://www.cidrap.umn.edu/newsperspective/2020/03/study-covid-19-mayspread-several-different-ways

Decree no. 2-A/2020, of March 18, 2020. Decreto do Governo que regulamenta o estado de emergência [Government decree regulating the state of emergency]. Available at https://www.portugal.gov.pt/downloadficheiros/ficheiro.aspx?v=3f8e87a6-3cf14d0c-b5ee-72225a73cd4f
DGS (2020a, online). COVID-19. Available at https://covid19.min-saude.pt/ DGS (2020b, online). Plano Nacional de Preparação e Resposta à Doença por novo coronavírus (COVID-19) [National Plan for Preparing and Responding to Illness in response to new coronavirus (COVID-

19)]. Available at https://www.dgs.pt/documentos-epublicacoes/plano-nacional-depreparacao-e-resposta-para-a-doenca-pornovo-coronavirus-covid-19-pdf.aspx

ECDC (2020a, online). Situation update worldwide, as of 25 March 2020. Available at https://www.ecdc.europa.eu/en/geographi cal-distribution-2019-ncov-cases 
ECDC (2020b, online). Rapid risk assessment: Novel coronavirus disease 2019 (COVID19) pandemic: Increased transmission in the EU/EEA and the UK - sixth update.

Available at https://www.ecdc.europa.eu/en/publicatio ns-data/rapid-risk-assessment-novelcoronavirus-disease-2019-covid-19pandemic-increased

PORDATA (2020, online). Private households with a computer, with internet access and with broadband internet access.

Available at https://www.pordata.pt/en/Portugal/Privat e+households+with+a+computer++with+i nternet+access+and+with+broadband+int ernet+access+(percentage)-1158

Portuguese Republic (2020a, online). Apoio às escolas [School support]. Available at https://apoioescolas.dge.mec.pt/Ferrament as?field_tipo_area_target_id $=$ All\&page $=0$ Portuguese Republic (2020b, online). Portugal EnCoDe.2030. Available at https://www.incode2030.gov.pt/en/incode 2030

RTP News (2020, online). Coronavírus. O que é e como começou? [Coronavirus. What is it and how did it start?]. Available at

https://www.rtp.pt/noticias/mundo/corona virus-o-que-e-e-como-comecou_i1203294

SIC News (2020, online). Covid-19:

Professores estão a ficar exaustos, alertam sindicatos [Covid-19: Teachers are getting exhausted, unions warn]. Available at https://sicnoticias.pt/especiais/coronavirus /2020-03-25-Covid-19-Professores-estaoa-ficar-exaustos-alertamsindicatos?fbclid=IwAR35_ExwHVwIU7 z6Yn1PTvmINFAgcStQsCawMpR2A1Gf LBAjKMeRJC1mQ6g

Teles, P. (2020). Predicting the evolution of Covid-19 in Portugal using an adapted SIR model previously used in South Korea for the MERS outbreak. Preprint. https://doi.org/10.1101/2020.03.18.20038 612.

Received: 18 March 2020

Revised: 30 March 2020

Accepted: 30 March 2020 